\title{
Leadership Development: Influence of Christianity on Akan Leadership Formation - A Case Study of Kwaebibirem
}

\author{
Ernest Koranteng Som ${ }^{1}$ and Kennedy Asenso ${ }^{2}$ \\ 1. Presbyterian College of Education, Kibi, Ghana \\ 2. .S.D.A College of Education, Asokore-Koforidua, Ghana
}

\begin{abstract}
The study investigated the influence of Christianity on Akan leadership formation in Kwaebibirem in the Brong Ahafo Region of Ghana. It was conducted using descriptive survey as its research design. The population of the study comprised chiefs, clan's heads and members of the clergy. Ten (10) were selected to form the participants for the study. These participants provided data for the study by way of interview in the form of focus group discussions. The data that was gathered by way of interview was analyzed thematically. It was found that the participants affirmed that Christianity has had influence on the traditional Akan leadership. Fetishism was also motivated as contributing to leadership development in the area. It is recommended that in order to preserve the core aspects of the traditional leadership system, there is the need for deliberate integration into the school curriculum at the basic school level in the Akan areas. Native language is to be used as the medium of instruction at the lower primary school. This is crucial to preserve and transfer the rich culture which involves education in the traditional and Christian institutions in the Akan areas. This will help blend the sweeping Christian ethos in modern Akan societies from which derive their identity and heritage.
\end{abstract}

Keywords: Traditional leader, Black Stool, Spirit

DOI: $10.7176 / \mathrm{JCSD} / 57-06$

Publication date:March $31^{\text {st }} 2020$

\section{INTRODUCTION}

\subsection{Background of the study}

Ghana has had a dual system of governance, the modern state system and the traditional systems that date back to pre - colonial times. The evolution of the modern system is traceable to British colonial rule that started in the early nineteenth century through gradual and subtle methods of encroachment on the sovereignty that was vested in the indigenous people led by their local rulers (Akoi 1978 cited in Asare, 2004). Among the methods used ere the gradual introduction of principles of English common law in deciding cases and the introduction of tax systems aimed at raising revenue to cover the cost of administration. Asare (2004) remarks that as the new system evolved, it did not obliterate the earlier indigenous system which the people has governed themselves.

However, colonial rule halted the evolutionary processes of the traditional administrative structures and undermined the basis of traditional rule that was rooted in moral authority and consultation by making organized physical force the primary locus of authority.

On another level, colonial rule gave traditional rulers, sometimes referred to as natural rulers, a new basis for their existence. The traditional governance system, on the other hand is the age - old method by which the indigenous people administered their affairs prior to and after the advent of Europeans into the region of modern Ghana around 1471(Akoi 1978 cited in Asare, 2004). Traditional governance systems varied considerably among the different peoples that occupied the region of modern Ghana while some groups developed very complex hierarchical structures, others had simple $\mathrm{Ki}$ - based types (asare, 2004). Asare adds that the matrilineal Akan - speaking people, for example, seemed to have evolved one of the highest forms of the complex system of governance. Asare continues that the Akan political system ensured social cohesion. Other groups like their Guan - speaking neighbors and the G- Adangme groups who originally practiced a religion - based system of government seem to have adopted and adapted the Akan model as could be inferred from the titles used for their political leaders. In the northern region, although there are such centralized states as Mamprussi, Dagbon, Gonja and Wa that have hierarchical structures with clearly defined rules of succession and titles for their officeholders, there are many others like the Tallensi, Konkomba and Gurunsi who until fairly recently did not have such systems (Asare, 2004). It is important to note that the history of the chieftaincy institution differs among the different ethnic groups and even in various administrative regions into which the country is divided.

The status and autonomy of traditional leaders also referred to as chiefs are guaranteed under the 1992 constitution and chiefs remain a significant force (the 1992 constitution of the republic of Ghana). Their continuing influence 
rest upon the economic, socio - cultural and political factors. Among the Akan's leaders possess control over lands; family wealth, cultural leadership where chiefs and other traditional leaders embody deep cultural values and practices, (e.g. the cult of ancestors, fertility of the land, taboos, festivals etc.

Mensah (2004) contributes that the chiefs are also a political representation of the community and community identity. This role has led to the frequent involvement of chiefs in party politics, either as brokers for the mobilization of support, or as powerful actors in their own right. Explaining further Mensah (2004) mentions that chiefs possess duty to work for the progress of the community. The material progress of a community, and the maintenance of its peace and unity, are seen as the principal duties of a chief.

This is embodied, where a community is united, in the chiefs' role as symbolic leader and patron of development/youth/ hometown associations (Mensah, 2004).

Mensah (2004) mentions that among the Akan's, chiefs are still seen as embodying governmental authority, because of the legacy of colonial indirect rule policies. Chiefs were a major element in colonial government, both at the local level (native authorities) and in central institutions such as the provincial council. Partly because of the roles chiefs played in colonial government, chiefly power was a focus for local opposition from traditional organizations of commoners and warriors such the Akan Asafo companies (Mensah, 2004). This form of local politics continues today in the form of the youth association, which in its developmental role both seeks the support and judges the performance of local chiefs. These local associations are easily and frequently politicized.

Opoku (2009) maintains that the desecration of African in the past by the Western European powers who introduced Christianity seriously and adversely affected the traditional cultures of the indigenous African people to the extent that many traditional beliefs, social values, customs, and rituals were either totally destroyed or ignored. In most cases they were considered to be nothing more than "pagan" values and superstitions that played no part in traditional African culture. To this end traditional leadership had its share.

Christians and traditionalist are believed to have been sending their petitions or thanks for divine protection to a higher than they are. Christians are believed to serve and worship God through Jesus Christ. On the other hand, the African Traditional are thought to revere the Supreme Being (God) through their gods and ancestors, that is, through divinity cults and ancestral veneration. Obviously, there exist certain differences and similarities in their respective beliefs and practices, taking cognizance of their ability to co - exist.

\subsection{Statement of the problem}

It has been said by Monmah (2009) that the world's largest religion, Christianity has had impacts on different cultures throughout the world. It leads to the infusion of certain elements of Christianity in the culture of societies which in one way has made most traditions lost originality. This may be true in most societies in Africa, Ghana and particularly Kwaebibirem in the Brong and Ahafo region. The meaningful growth and development of every country must be based on a strong culture of leadership as culture is not merely a return to the customs of the past (parker, 2005) it embodies the attitude of people to the future of their traditional values faced with the demands of modern existence which demands essential factor of development and progress. But to what extent has Christianity influenced the Akan leadership formation?

Having lived, studied, worked and worshipped in some churches in the Kwaebibirem district for about 40 years, the researchers have noted that some aspects of traditional leadership has been changed by the teachings of Christianity with new churches springing up on regular basis in the area it is that most, if not all aspects of traditional leadership has, should reflect the teaching of Christianity in the Kwaebibirem.

\subsection{Purpose of the study}

The purpose of this study was to look at leadership development of the Akan and how it has been influenced by Christianity.

\subsection{Objectives of the study}

the study sought to:

1. Identify the leadership formation role in the Akan traditional system

2. Find out whether the Akan leadership practices waning.

3. Find out Christianity leadership practices are impacting on the Akan form of leadership. 


\subsection{Research questions}

The following questions were asked to guide the course of the study

1. What is the leadership formation roles in the Akan traditional system?

2. Are the Akan leadership practices waning?

3. How are Christianity leadership practices impacting on the Akan form of leadership?

\subsection{Significance of the study}

The researches intend to broaden the knowledge of the researcher and readers of this thesis about Akan leadership formation and how they have influenced by Christianity. The Akan indigenous leadership system plays a significant role in traditional governance and Christian leadership formation. It is therefore hoped that the findings of the study will add to the existing literature. The study will provide traditional Christian leadership system a source of reference material for the scholars and educators in the respective fields that will benefit student teachers and educational interventions.

\subsection{Delimitation of the study}

The research is mainly limited to Christianity and Akan traditional leadership in Kwaebibirem, the Brong and Ahafo region of Ghana, and assess their impact on the wellbeing of the people. The study was limited to the use only interviews in collecting empirical data from participants.

\section{8 limitation of the study}

Most of the interviewees selected were uncomfortable with the English language. Therefore, the researcher was compelled by the circumstance to conduct the interviews in Twi. This made it tedious and difficult translating it into English for the study.

\subsection{Organization of the rest of the text}

after the introductory chapter (chapter one), chapter two critically reviews related literature of both theoretical and empirical work done in the areas of Akan traditional leadership and how it has been influenced by Christianity. Chapter three is devoted to research methodology of this thesis. Chapter four deals with data presentation analysis and discussions chapter five focuses on summary, conclusions and recommendations.

\subsection{The concept of traditional leadership}

Okrade (2008) posits that successful transformation of societies greatly depends on the role and decisions taken by chiefs who are seen as leaders of the society. That is why a Leader with a vision is required to achieve quality leadership skills in the community. A leader acts in both formal and informal ways to build the commitment of his people.

Yadian (2006) revealed that leadership has significant impact society's satisfaction and commitment to achievement of goals.

Ibaeli (1995) posits that the traditional leader is required perform three vital functions.

These are, to discern and influence the development of goals; to establish and coordinate systems of traditional governance concerned with planning and implementing appropriate programmers; and to procure and manage the resources necessary to support the community and its planned programmers. Abe (2011) postulate that the phenomenon and the subject of leadership has gained a considerable attention, discussion and extensive study by theorists and researchers in a number of disciplines. Citing Bono and Judge (2004), Jiao (2008) contend that there has been great interesting the influence of personality within the leadership dyad and numerous outcomes associated with leaders. Avery (2004) indicates that some leadership emergence or behaviors may appear effective in a situational context bit may be seen as ineffective in another. This study looked at how traditional leadership has been influenced by Christianity. 


\subsection{Christian leadership}

Leadership in Christianity is guided by the life of Jesus and great apostles mentioned in the Bible. Adair cited in Hanson (2009) draws attention to the fact that Jesus possessed a genius for leadership. It is therefore reasonable for Christians to believe that the example of leadership set by Jesus out to be better known to Christians and to be practiced more widely. Hanson (2009) maintains that Bible is the greatest book on leadership ever written. As well as including the story of Jesus it also tells of people before Him who, putting their faith God, allowed God to lead them; and of people who. After Jesus' life and resurrection, sought the help of God the Holy Spirit to guide them in the way ahead. Furthermore, Christianity has a rich heritage of wisdom, and effective leadership requires wisdom.

The authorities in Rome, responsible for governing and administering this vast far-flung empire, appreciated the importance of leadership. They expected those in authority under Rome to demonstrate timely practical leadership. In particular, they emphasized the great importance of leaders thinking ahead so that they developed for sight that would help them to have a clear vision about the future tasks. They were then expected to share that vision with those they led. The Romans expected their leaders to be totally committed to the task in hand and to expect a similar commitment from their own subordinate leaders. Thereafter Rome required its leaders to identify clearly and precisely what had to be done and o delegate accordingly. These thoughts on leadership and no doubt many others were probably well known in the Holy land during Christ's early life. Almost certainly they were known to the Roman procurators.

An early example of the moral leadership of Jesus was shown while He was still a young man in Judea. He was led by the Spirit into the desert where He fasted for forty days and night and was tempted by the evil many times. Finally, Jesus said: "Away from me, Satan! For it is written: worship the Lord your God, and serve him." (Matt 4:10).

Serving the will of God was the mission of Christ's Ministry and it was Him remarkable leadership that led to the formation of Christendom.

Ntumy (2003) remarks that Christian leaders are often simple, ordinary Christians, who having received a calling into ministry, have mostly been trained on the job. They consider theological education as very important, but over the years this has not been allowed to determine the choice of people for ministry. These were the men McKeon used and to a large extent the church has relied on and has achieved tremendous results in its activities, they were men and women the indigenous people could freely identify with because they ate with them, slept amongst them and understood their fears and problems. With such a caliber of personnel, it was not difficult to identify leaders for the numerous fledging churches. Leadership was therefore not a serious challenge for them since they did not believe in any vigorous theological training for their personnel but the only requirement was someone who was saved and baptized in the Holy Spirit.

\subsection{Akan leadership during colonial times}

Throughout history, traditional leaders have held the position as a type of governor whose all-encompassing authority extends over all and sundry from judicial functions to social welfare (Tshehla 2005, p.1).during the $19^{\text {th }}$ century traditional authorities endured a period that was characterized by a great number of changes. Colonial governments had the power to not only select and appoint traditional authorities but to also designate or relocate the traditional authority's areas of jurisdiction (IPT, 2006). The age old system of appointment on the basis of hereditary descent was not abolished. Moreover, the traditional methods used to appoint tribal councilors were regarded; very few councilors were elected due to the fact that the chief appointed a large percentage of the councilors. Consequently, tribal authorities were dispossessed of the pre - colonial regulatory. Measures and systems that previously used to temper chief's powers (Khan and Lootvoet, 001, p.3).

During the colonial era, chiefs were incorporated into the colonial government's administration. The very fact that the colonial administration remunerated chiefs on the basis of their position as traditional leaders, as well as the way in which the colonial government not only restricted and defined chief's role and duties points to the fact that for all intense purpose chiefs appeared to be employees of the colonial government (Palmary 2004, p.12). Little changed in terms of the payment and definition of chief's responsibilities under the new governance system. Under both the colonial and present administrations, traditional leaders in effect primarily answered to the government of the days as opposed to the communities over which these leaders resided over (Palmary, 2004:12). Moreover, in pre - colonial times, there were systems and channels in place that allowed communities to contest chief's decision and actions. Traditional authorities were therefore accountable to their communities. These 
systems were displaced under the colonial (Palmary 2004, p.12). In short during the colonial, the traditional leaders were dispossessed of any form of role in the delivery of service (Khan and Loovoet 2001, p. 4).

\subsection{The Akan and their cultural setting}

Religious and cultural pluralism has been a prominent feature in human societies and this became intensified with the impact of modernity. The phenomenon of such pluralistic experiences presents opportunities as well as challenges, particularly, for religious tradition and cultures today Acquah (2011). Akan -one of the principle races in west Africa, inhabiting the Gold Cost, Ivory Cost some parts of the French West Africa, up to old Kingdom of Ghana (near present Timbuktu), and speaking Twi (Twi) language. The best known representatives of the race are the Ashanti. Fanti, Akim, Akwapim, Assin and several of the present day (Twi speaking) races of Gold Coast (modern Ghana) and Ivory Coast (cote d'Ivoire). some common characteristics about the Akan group are their kingship (leadership) system in well hierarchical centralized states, their religious practices (polytheism) which is also clearly pecking order in form and practice, the language (Twi) and the seven totem to mention but few (Danquah, 1968).

In Ghana they are the largest ethnic group. This group consists of tribes such as Agona, Aafo, Ahanta, Akuapem, Akwamu, Aowin, Asante, Assin, Fante, and Kwahu etc. the 2000 population census reports that the Akan constitute $49.1 \%$ of the total population of 18,800,000. They occupy sic out of the ten regions namely Ashanti, Eastern, Central, Western Brong Ahafo and Northern Volta.chinebuah et al. (1976), have also noted that, the Akan language (also known $\mathrm{Ti}$ - Fante) is group of dialects within the Kwa branch of the Niger-Congo language family Chinebua etal. Also included under the term 'Akan' are Bia languages (in which case is common to speak of Akan languages", as a group of languages).

Traditional Akan remains a culture guided by religious norms: the first to realize is the close bond that exist between religion and social life. The African religions impregnate the whole life of the community. They are the beginning and the end of everything. Reduces to essentials, their world view their vision of the world, is a unifying factor, because it does not imply any clear-cut difference between the profane and scared, between matter and spirit, (Douglas 2005).

A careful examination of the Akan indigenous perspectives of the chieftaincy institution point to the fact that there is much theology in the institution that must be considered in the construction of Akan Christian understanding of chieftaincy institution. The Akan indigenous leadership formation perspectives provide the process for the theological construction of Akan Christian leadership theology.

\subsection{Traditional leadership institutions of the Akan}

Crook (2005) defines traditional institutions in the country as comprising all those forms of social and political authority which have their historical origin in the pre - colonial states and societies, and which were incorporated by British colonial rule into what is now Ghana. On this definition, traditional institutions are very varied. He further stressed that indigenous traditional institutional institutions are ver dynamic and have gone through changes over time. Although indigenous in origin, they have changed in many ways during the colonial and post-colonial periods. They are living institutions, not museum pieces. At one extreme, some Ghanaian societies had extremely hierarchical, militarized forms of kingship of chieftaincy. These varied according to how the rulers were chosen. Amongst the Akan peoples of Southern Ghana, for instance, the Asantehene was once the ruler of an empire which dominated most of Southern Ghana and its eastern and western borderlands. Today, he is the leader of traditional state, which is also an administrative region, inhabited by over two million people. He commands the allegiance of a roup of paramount chiefs who rule the federated Asante states (oman) in a hierarchy which is replicated down to the village chief level.

Opuni - Frimpong, (2012) asserts that, the Akan's attached must importance to the formation of their leaders and that the nature of the Akan indigenous leadership formation can be seen from the during the pre-installation, confinement and post - installation phases. These according to him have seen some changes due to Christian influence and an more importantly Western style of education, many contemporary Akan traditional leaders have received missionary patterns of education of education and might have as well been involved in Christian leadership and that some might have reached the highest form of university education.

Although the Asante king's offices is hereditary, in that we must come from a royal matrilineage, he is chosen by group of kingmakers in a very competitive process from among a potentially large number of candidates. He can be removed (destoned) if the kingmakers deem him to have breached his oaths of office, although this is not easy 
process, and frequently provokes violence. This model of Akan kingship can be found throughout southern Ghana in all Akan societies (Crook, 2005).

\subsection{Akan leadership development}

Akan leadership, that is the governmental system involves how leaders make and maintain law and order, their security systems, their election of chiefs, their court systems and many others, in the Akan leadership system, the chiefs, queen mothers and elders form the government. Busia (1968, p. 21) writes, "The chief was subject to checks from the elders, but they were jointly responsible for the administration of Division. They formed the Government". Busia left the queen mother out, but in reality Akan leadership administration will never be complete without the queen mother. It is important to examine the role music, dance, drama and the drum play in Asante's political system in that, they are portrayed in almost all the activities within the political system: the enstoolment, duties, death and burial, duties, death and burial of a chief.

In the Akan political set up, no one can become a chief if he has not been nominated by the Obaahemaa from the appropriate royal house, Busia writing on the nomination of a new chief for the Wenchi Traditional Area made this observation:

When a chief died and a new one had to be appointed, the elders held a meeting at which the Kontihene presided. At the meeting the selected two from among themselves to approach the queen-mother and ask her to nominate a candidate for the stool. The queen mother then held a meeting with all the adult men and the senior women...of the eligible candidate in turn and chose the one they considered most suitable. According to Asare (2008), the Obaahemaa had three chances of producing a candidate acceptable to the community. If she failed, the representatives of the community could select a candidate.

Adotei and Hagan (Eds) noted a similar procedure as Busia in the nomination processes that culminated in the selection of Barima Kwaku Duah who was enstooled as Otumfour Osei Tutu II, Asantehene in 1999. The processes were set in motion after the burial of the late Asantehene, Otumfour Opoku Ware II. Seven candidates express interest in the vacant Golden Stool, the symbol of authority of an Asantehene.

The status and autonomy of traditional leaders also referred to as chiefs are guaranteed on the 1992 constitution and chiefs remain a significant force. Their continuing influence rests upon the economic, socio - cultural and political factors. Among the Akan's leader possess control over lands; family wealth, cultural leadership where chief's and other traditional leaders embody deep cultural values and practices, (e.g. the cult of ancestors, fertility of the land, taboos, festivals, etc. Mensah (2004) adds they the chiefs are also a political representation of the community and community identity. This role has led to the frequent involvement of chiefs in party politics, either as brokers for the mobilization of support, or as powerful actors in their own right. Explaining further Mensah (2004) mentions that chiefs possess duty to work for the progress of the community. The material progresses of a community, and the maintenance of its peace and unity, are seen as the principal duties of a chief. This is embodied, where a community is united, in the chiefs' role as symbolic leader and patron of development/youth/hometown associations.

It must be well noted that the power to nominate a person to occupy a vacant stool among the Akan is the sole prerogative of the Obaahemaa, recognized by the supreme court of Ghana when in a landmark case brought before it ruled that the enstoolment of one Kwadwo Nam Nketia as paramount chief of Wenchi, a town in the Brong Ahafo region of Ghana was null and void because the nominee did not have the blessing of the Obaahemaa of Wenchi Traditional Area, Nana Atoaa Sramgyedua III.

The case as Bimpong - Buta report is as follows. Nana Abrefa Mbore Bediatuo VIII CHIEF OF Wenchi died. After his death there arose a dispute with one Nana Kusi Appea, a former chief of Wenchi, staking a claim for the vacant stool. The case was resolved by the Brong Ahafo regional House of Chiefs. The house ruled in favour of the Wenchi Obaahemaa who had opposed Nana Kusi Appea. After the resolution of the dispute by the house of chiefs, the king makers of Wenchi requested the Obaahemaa to make a nomination for the vacant stool. The Obaahemaa responded that the needed three weeks to make her choice. This did not go down well with king makers since they could not wait for that long. The Obaahemaa relented and still insisted of being given three weeks to make up her mind since she needed to do wide consultations.

Mensah (2004) mentions that among the Akan's, chiefs are still seen as embodying governmental authority, because of the legacy of colonial indirect rule polices. Chiefs were a major element in colonial government, both at the local level (native Authorities) and in central institutions such as the joint provincial council. Partly because 
of the roles chiefs played in colonial government, chiefly power was a focus for local opposition from traditional organizations of commoners and warriors such as the Akan asafo companies. This form of local politics continues today in the form of the youth association, which in iys developmental role both seeks the support and judges the performance of local chiefs. These local associations are easily and frequently politicized.

The Akan is made up of the Adanse, Asante, Akuapem, Awamu, Akyem, Assin, Brong Ahafo, Denkyira, Fante, Gomoa, Kwahu, Sefwi, Twifo and Wssa. The Akan is organized into eight clans with each identified by a totem. Clans, generally, are the largest family groups, members of which believe in their common descent, by birth, from a common, though unknown, and nameless ancestor or ancestress. The family or Abusua is matrilineal and each Akan belongs to one of them. Every person whose mother is an Akan belongs to one of these Abusua, and it is along these lines that inheritance is determined with regard to Akan stool or family properties. Warren (2006) using the Asante as an example makes this points:

The political organization of the Akan is largely on the kingship, each lineage beinga political unit with its own headman acting as its representative on higher councils. The household head is mirrored in instituted officers of progressively larger political unit; for the Asanti their hierarchy begins with the household head... (abusua panin), the village headman (odikro), the territorial chief (ohene), the paramount chief of a division of the Asante Confederacy (omanhene) and finally, the head of the Asante confederacy, the Asantehene.

At each level of the Akan political structure the stool is the symbol of authority and each level has a stool for the Obaahemaa and Ohene (male chief) respectively. As noted above, the office of the traditional ruler has evolved right from the inception of the establishment of polities within the region of modern Ghana. As a collective, it is also referred to as the chieftaincy institution. Indeed, in Ghana, the institution dates back several centuries and remains the prime custodian if Ghanaian culture. The institution is much revered and held in awe while at the same time it is perceived to be the embodiment of the spirit of the ancestor and a link between them and the living community, additionally, it provides a renewed sense of belonging as well as being a powerful agent of social cohesion and harmony. The office of traditional rulers has been transformed as it has passed through various phases back to the pre-colonial era through the colonial period to the present

Akan leadership according to Parker (2011) is associated with fetishism. Why the word fetishism has caught on as a description of one form of Africa traditional religion is again one of those mysteries. The word derives from the Portuguese word feitico which means an object or an article. Discovering that the West Africans they men on the coast were wearing objects of religious value like charms, talismans and amulets, the Portuguese imagined that the religion of West Africans was a worship of such objects.

One need not belabor the point that this is a great injustice. What about the wonderful names given to the Supreme Being and the horrific appellation he enjoys among us? The truth of the matter is that there is no religion in the world that can be called fetishism. And if because sacred objects are found in Africa traditional religion, the religion is fetishistic, then we find ourselves in deep waters. There is no religion in which such objects are not found. In Christianity we respect status and crucifixes, medals and rosaries. They, too, are objects. But we understand that these are secondary aspect of the Christian religion. Do they not also use prayer-beads? Do the Muslims not venerate the kaaba? Similarly, idolatry which simply means the worship of idols according to Parker (2011) is associated with Akan leadership. The ideas found in African traditional religion comprise the belief in a Supreme Being, the ancestors, the lesser gods and powers and potencies. Why such a religion can be linked with the worship of status, pictures or images representing divinities which is how the Pan English Dictionary defines the word "idol" is another of those inexplicable stereotypes. Even if, for the sake of the argument, it is admitted that lesser gods are idols one worshipped, then they form only part of the religion and, therefore, cannot be made to represent the whole religion. It is obnoxious to call African religion idolatry.

\section{7 perspectives on African Traditional Religion}

Culture, after all, is the way of life developed by people as they cope with survival. True culture then must include the traditional beliefs and spiritualism. In any case, at a certain point, the period of scorn for, or misunderstanding of African culture gave way to a period in which it was recognized positively valued. (www.afrilaworld.net).

While this is not quite true of the culture, it certainly is of its principal and fruitful element: the religious phenomenon. Its complexity is such that in order to define it several terms were invented by ethnologist: superstition, fetishism, animism, totemic, monism, magic and paganism. All these terminologies express not only the complexity of the phenomenon, but also the awkwardness which its inventors felt when faced with such 'inferior' forms of religion. 
The most important thing is that it has been recognized that Africans have religions, or a religion, where these Africans have always been known universally as highly spiritual people. All agree in the recognition of the Supreme Being's location at the summit, in the structure of traditional religion in Africa. And if one considers it in its highest form - the mystical - one realizes that it presents not only a sort of natural mysticism, a mysticism of insight, a mysticism of immanence, but also mysticism of God's depth. A yearning of the soul for irrevocable union of the individual with God. Indeed, in Africans, who experience intensely this vertical dimension of their spiritual life, there is a deeply felt sense of direct participation in the existence of God, inwardly perceived as unique, immense, hidden, rich, "burning", and just good. So that, as has been noted, African mysticism is like others, an authentic, fascinating, complex and beautiful form of mysticism, one of the springs where parched souls can quench their thirst.

\subsection{Christianity in Africa today}

There has been tremendous growth of Christianity in Africa. As evidence, only nine million Christians were in Africa in 1900, but by the year 2000, there were an estimated 380 million Christians. According to a 2006 Pew Forum on Religion and Public life study, 147 millions of African Christians were "renew list" (a term that includes both Pentecostals and charismatics) (www.wikipedia.or/Christianity_in Africa.htm). much of the Christian growth in Africa is now due to Africa evangelism rather than Western missionaries. In South Africa, it is rare to find a person with no religious beliefs, which is almost always Christianity amongst the whites, but Christianity is also popular amongst the blacks, especially city-dwellers. Christianity in Africa shows tremendous variety, from the ancient forms of oriental orthodox Christianity in Egypt, Ethiopia, and Eritrea to the newest African-Christian denominations of Nigeria and Ghana, countries that have experienced massive conversion to Christianity in the recent time.

Some experts tell about the shift of Christianity's center of gravity from the Western industrialized nation to Africa, Asia and Latin America in modern times. A Yale university historian stated that "African Christianity was not just an exotic, curious phenomenon in an obscure part of the world, but that African Christianity might be the shape of things to come." (http:/www.wikipedia.or/Christianity_in_Africa.htm).the statistics from the world Christian encyclopedia (David Barrett) illustrates the emerging trend of dramatic Christian growth on the continent and supposes that in 2025 there will be 633 million Christians in Africa (www.wikipedia.org/Christianity_in_Africa.htm).

\subsection{The cultural incubation of the Christian gospel}

Christianity which started in Jerusalem with a Jewish background passed through or moved across many cultures. From Jerusalem it moved to Asia Minor and Egypt in North Africa and then through Greek, Roman, German, British and American regions. Throughout these journeys Christianity has adopted many cultural elements along the way. Christianity then has more or less become a beggar of some sort. In the end, as a beggar, wherever Christianity has been propagated, "it seeks for food and drink, as well as cover and shelter from cultures it encounters in its never ending and winding journeys and wonderings.

The result is that today Christianity seeks to be integrated within the cultural elements of the people of Kwaebibirem district. The true observation, a seen in the lives of the Christians found in Kwaebibirem district, is that there appears to be dichotomy or division between Christianity and the cultural elements or worldview of the Akanfo] of Kwaebibirem. In the end, the indigenous people of the Kwaebibirem district area who go to church feel alienated from their worldview. For, there are some indigenous Akan cultural elements which are similar to what is found in the Bible. However, as a result of the church's doctrines the Akan Christians of Kwaebibirem district are not very sure as to what to do with such cultural elements.

Apart from everything else, Christianity has been incubated, nurtured and developed through the language of the Akan people of the Kwaebibirem district. To state, therefore that some cultural elements of the Akan people of the Kwaebibirem district have influenced the way the gospel is received and practiced" in the Kwaebibirem area would not be an exaggeration. Apart from the Akan language influencing worship in the Kwaebibirem district, in most of the Christian churches in the Kwaebibirem district metrolitant area, according to Agyemang, (1988,59), both male and female worshippers do obeisance whenever they go for Holy communion at the sanctuary. In addition, whenever Akan Christian worshippers of Kwaebibirem shake hands with their priests, they do obeisance. This is exactly how the Akan of the Kwaebibirem district show respect to their traditional chiefs and elders.

According to Agyeman (1968, 59 - 60), while the women bend down their knees, the men bow down and remove the African cloth covering their left shoulders, making them bare as they take Holy Communion in front of the 
sanctuary. Some older worshippers in churches seven walk bare - footed to take Holy Communion at the sanctuary. This happens because in the Akan religious worldview, no one enters the shrine of a deity wearing sandals or even shoe. When such cultural elements plus many more are effectively incorporated into the liturgy of the church in the Kwaebibirem area, it will show the form of Christianity being practiced in the Kwaebibirem district.

One obvious fact is that most of the converts to Christianity in the Kwaebibirem district are at times faced with a dilemma. This happens because the Christians are not too sure as to how to relate with their cultural values, now that they have become Christians. Some of such ne Christians are functionaries of the royal palaces of Kaebibirem district. Such people are in a dilemma as to what to do some occasions. They are not sure of what to do in matters of libation, playing of the drums and other indigenous instruments in the palace. Their confusion arises from the fact that to most Christian leaders such ceremonies are said to be associated with abosom and ancestral worship.

In Adubofour's (1987, p. 71) view as a result of the contacts made between the Akan and the outside world, especially the Europeans, there have been many adaptions which outlook of the Akan people in general remains intact'. Referring to a comment made by Busia, Adubofour 1987, 71), further states that 'the observation that Busia made some years ago on the Akan worldview. (particularly the Asante) still holds true today'. That means, although the Akan people of Kwaebibirem district have had a long association with the outside world, and have copied or learned and adopted cultural values from the outside world in order that Akan culture should be enriched, the world view and cosmology of the Akan people of the Kwaebibirem district still remain Akan.

From the viewpoint of Adubofour (1987), when writing about the Ashanti people around the middle of the last century, Busia stated that 'he world outlook of the Ashanti and their interpretation of the universe have been but little affected by the turbulent events of the last three hundred years; (since the European contact), they have held largely to their ancestor beliefs and practices'. Adubofour $(1987,101)$, then think that this 'persistence of Akan beliefs and practice inspite of the contacts with the outside world is grounded in the Akan saying that "amammer[,y[nto ntwene, amammer[y[ntoton'ase", that is "culture should not be discarded ; culture should not be dishonored". As a result, although the Akan people of the Kwaebibirem district metropolis have learnt a lot through formal education and Christianity, their worldview on certain issues have not changed much.

In spite of this idea of the Akan people of the Kwaebibirem district Metropolis holding on firmly to their worldview, the early Western missionary churches felt that the church

Was the only legitimate custodian of the Christian faith. The missionaries therefore fought tooth and nail to preserve 'the sanctity' of the church by sticking to western culture, and civilization as the forms of philosophy for the church in Kwaebibirem district. In the words of Shorter (1988, p. 18), in the middle ages, with the adoption of the Greco - Roman philosophy 'the immutability of the Christian cultural ideal was sealed'. Any other cultural format, however relevant it was, which was incompatible with European values, was then considered unacceptable to the true Christian faith. For example according to Julius Richter, a protestant German missionary to Africa, Ranger, (1927, p. 259), some Akan cultural elements are 'poisoned by so many excrescences of pagan superstition and unbridled sensuality".

This means that they teaching that did not follow the European factor or philosophy was simply unacceptable, as it was "poisoned". in this way, every concept of theological expression or idea, or Christological knowledge, which was thought to exist in 'objective forms' was securely 'within the tutelage of the church and was neither open to personal interpretation upon cultural factors', Clark, (2006, p. 24). However, Laryea (2002, p. 35), believes that 'no longer I theology to be regarded as the preserve and monopoly of western intellectual thought, nor can we continue to think of theology as belonging solely to the academy'. The people who are involved in the development of Christian theology who, according to Laryea (2002, p. 25), 'are in the open fields and are therefore grass root theologians'.

It is rather unfortunate that quite a long time, some people, both Europeans and Africans, held the view that some cultural values, especially those of the so called 'Third World', were so inferior that they could not be used in academic or theological circles, much more so in Christian divine worship. All other cultural values, apart from European cultural values, were described as 'primitive' or 'barbaric'. In such a situation, those 'primitive cultures' were of no value to academia and religious discussions, including Christian worship apart from such cultural values being spoken of in those derogatory terms.

As Opoku (1978, pp. 1-2) declares, it was very clear that all the previous writers showed their is by being influenced by what others had written. In addition to that it looked like each writer had an interest or agenda to follow in their writings. This, as Opoku indicates shows that even in the writings of the early missionaries the Akan people of 
Kwaebibirem were represented as a 'people immersed in crippling superstition'. The religion of the African, and for that matter, the Akan of the Kwaebibirem district, "lacked any abiding values", so that the Akan people could become 'objects' for evangelization.

This unfortunate idea of looking down on cultural elements was carried into church, thus affecting the use of indigenous cultural elements in the development of a relevant Akan liturgy within Kwaebibirem district. When Lucas, according to Ranger, (1927), an Anglican Bishop in East Africa tried to indigenize church worship in his diocese, one of his priest stated that the idea of indigenization was full of 'un-Christian teaching given by way of song, dance, story and suggestion' the priest stated categorically that he did not want to have anything to do with the indigenization process because to him, so far as he aware, 'I have not yet met anybody, except our bishop who believes', in the whole idea of seeking to influence Christianity with African culture. Sarpong (2010), reports of a similar thing when e sought to develop an Akan liturgy for the Mass for Roman Catholic Parishesin the Kwaebibirem district. Some four Irish priests working with him in the Kwaebibirem Diocese initially insulted him but on that, but apologized to him later on.

This concept of the demonization of Akan and for that matter, African cultural elements was clearly demonstrated in East Africa by the Roman Catholic church. According to Schoffeleers and linden $(1972,259,256)$, 'the first missionaries branded the Nyau an East African cultural element among the people of Chewa in Malawi), as "immoral" without taking the trouble to understand "its social and religious significance". one thing the missionaries failed to observe, was the fact that 'the performances of the dancers make up a liturgical celebration'. To the white missionaries, the Nyau was immoral because of the 'absence songs and the appearance of naked dancers in the presence of women'. However, dance which took place 'during the day-time without mixing the sexes were viewed Favorably by the same missionaries.

Instead of having a "mutual engagement" the church and the indigenous people were at each other's throat. One of the result of such a hostile atmosphere in Malawi was that a Christian young man was almost lynched to death because according to the traditional people, 'despite warnings he had been repeatedly caught by Nyau members singing the secret songs in public'. In spite of it all, according to Ranger, (1927), the white missionaries were not prepared in any way to come to terms with realities and such as 'the confrontation continued at countless Milan's between Christians and the Nyau'.

However, the Nyau through one of their leaders, spoke very clearly to the missionaries and the trained local catechist telling them, 'we Chewa cannot allow our customs to disappear.

They are the precious legacy of our ancestors'. In the words of Sarpong, (2002, p. 37), when doing enculturation,' one has to look for symbol in one's society that stands for what the church wants one to express'. To him, doing enculturation 'is not a glorification of the past, as if nothing in the past was wrong. Nor is it a blanket condemnation of past as if nothing in the past was right or good. However, in the East African experience everything African was wrong. The truth of the matter was that the Nyau was the cultural heritage of the Chewa speaking people of Malawi. To these people therefore, were very proud of it, irrespective of what the white missionaries taught. The Nyacult, as stated by Ranger, (1927, p. 270), was 'their greatest store-house of religious ideas and their most elaborate religious ceremony', but to the white missionaries and their local catechist, 'the Nyau is a great impediment to progress in Malawi'.

However, in the words of Ranger, (1927, p. 271), to the members of the cult, their performances were not a 'savage expression of something sinister but a part of our training to instill discipline, good motherhood, fatherhood and citizenship', into the youth.

The limitation ceremonies of the young Akan men and women have their own forms of training.

As much the Chewa people of Malawi, like the Akan people of Kwaebibirem district, have developed their own system of instructing the youth with the accompanying liturgies and do not need depend on the European for guidance. When the Europeans tension and acrimony were generated. This showed a lack of feeling and understanding for the people's cultural values. Indeed, in Malawi the usual name - calling was at play. The Nyau was said to be 'reactionary' and 'retrogressive' by the missionary team. Yet the Chewa people refused to be intimidated, and as such 'the cult maintained itself for more than half a century against the most highly organized and 'cultic' of the Christian churches' (Ranger 271).

The assumption by the early western missionaries that since they were in Africa to bring salvation and civilization to the 'barbaric natives' and as such 'traditional social institutions, with their religious core, must quickly disappear 
in the face of prolonged and intense pressure from churches' is totally false, (Ranger, p. 271). What happened in Malawi as result of the resistance by the Nyau 'provides and eloquent testimony to the conservative strength of traditional religious institutions' anywhere in Africa.

\subsection{0 influence of Christianity on Akan leadership formation}

Williamson $(1965: 159,164)$ in comparing Christianity and Akan religion argues that the church established by the Western Missionaries made phenomenal gains both in propagating the Christian religion and in acting as a cultural force, yet it was unable to directly address the people in religiously convincing terms. These missionaries therefore failed to satisfy the spiritual need of the Akan. He further explains that the western Mission-related church by and large is still an alien institution because it failed to properly contextualize it worship in the life and institutions of the Akan people in that, the Christian church denominationally implanted from the west, has substantially retained its original forms and expressed itself in western modes. Missionaries clearly set out to establish not and Akan church, but the church they represented in their homeland. The polity and organization, the liturgies and devotional expressions, the discipline and instruction, the total outlook derives directly from the parent missionary societies and churches supporting them. The Christianity of the Akan area proves to be the denominational Christianity of the west.

He continues that by the assault of the missionary enterprise on traditional beliefs and practices, and by the nature and method of its approach, the implanted Christian faith denied the Akan outlook in fierce and abrupt terms, and thus failed to meet the Akan in his personally experiences religions need. The Akan became a Christian by cleaving to the new order introduced by the missionary rather than by working out his salvation within the religious milieu.

Williqnson's observation, like that of many other writers, raises several significant issues. Central to all these issues is the relationship between faith and culture. At the center of every culture lies the world view of how people perceive, understand and interpret reality. Though the situation today about the mission churches has changed considerably, it is very easy to still find remnants of the western style of worship in their activities.

Larbi (2001, p. 7) indicates that every culture has within it religion system, certain practices directed towards the achievement of what is considered the highest good. He further explains that, religion, by its nature and purpose, should be holistic: addressing the total person: spiritual, physical and emotional, providing authentic answers to the person's everyday quest, fear, and anxieties thus if a particular religious system fails to address what people feel that their whole existence and survival hinge on, that system is bound to be rejected and frowned upon when people are confronted with the real issues of life. Larbi's observation accurately captures the major reasons why the churches which came onto the scene several years after these mission churches have firmly rooted themselves in the soil of Ghana were able to grow at such astronomical rate overtaking some of these mission churches in numbers and church attendance, the reason for such a phenomenal growth is not farfetched; these Pentecostal churches were able to place themselves as a better alternative to these mission churches.

\section{The engagement of the gospel and culture}

In Christian evangelization, there is always and engagement, which in the words of Bediako (1975 cited in Asare (2008), is an 'engagement of gospel and culture'. This engagement, Bediako further adds, should however, be more than just the transformation or alteration of surface elements like music, dance and artists'. It should be seen as more than a dose of 'spiritual salvation' which is applied to the local people. It should also not be a question of the 'demonization of our culture'. Rather, the 'gospel and culture engagement is about the conversion of cultures... of all that is there in us, about us and around us that has happened us'

Bediako (1975) continues to argue that in evangelization there is an 'engagement' between culture and the good news. Such an engagement should lead to the situation where each influences the other for their mutual benefit. However, Bediako believes that 'it is the gospel that is anterior or prior to culture and not our culture which is prior to the gospel'. In that situation, the persons being evangelized, as in this case the Akan people of the Kwasebibirem district metropolis, should be seen a coming from a particular stand point or worldview.

The new religion, in this case Christianity, should not dehumanize the cultural elements of the Akan people of the Kwaebibirem district metropolis. For that reason, the Akan people of the Kwaebibirem district should not be looked upon as empty containers' which needed to be filled up with gospel message. The Akan people of the Kwaebibirem district worldview, in this case their cultural background, made up of their cultural elements, should have been seen as being worthy of conversion also. Bediako $(1975, \mathrm{p} .2)$ continues to argue that 'it is the gospel, not our culture, that defines us as human beings'. 
Through this process of evangelization, many converts have been won over the years into the Christian faith in the Kwaebibirem district. A major issue that need to be considered, then, is how these new converts of the Kwaebibirem district have related to their cultural elements and how these culture elements have influenced their worship in the new found faith. This process of integration of cultural elements and the Christian faith has been a long standing issue. For, according to Afriyie (2010), 'that this has been an issue is seen in the number of writings there, and the conferences that have been held, on the relationship between a convert and his culture'.

In Addae-Boateng's view $(2001,40)$, 'the early missionaries had good intentions for introducing Christianity into Ghana, then Gold Coast, in the $18^{\text {th }}$ and $19^{\text {th }}$ centuries'.

However, Addae- Boateng thinks that the missionaries did not do much in building the gospel message on the Ghanaian culture. In most cases the missionaries presented the Christian faith in their culture'. The result of such an attitude was that the indigenous people of the Kwaebibirem district metropolis 'associated Christianity with Europeans and Christian practices with European culture'. However, Addae-Boateng (2001, 35), like Bediako, thinks that 'indigenous cultural elements and Christianity should have enriched one another through enculturation'.

Since this "mutual enrichment" between cultural elements and the gospel has not fully taken place among the Akan Christian community of the Kwaebibiem district metropolis, there has been a continuous 'debate on the relationship between the gospel that is proclaimed to make to make converts and the culture of the converts', (Afriyie, 2010, 2-3). This fact about the relationship between cultural elements and the gospel shows how cultural elements should be seen as having a very strong influence over people. This strong influence of cultural elements in the lives of people is seen among the Akan of the Kwaebibirem district too.

A critical evaluation, however of Akan Christianity as seen in the historic churches, that is the Presbyterian, Anglican, Methodist, Roman Catholic churches in the Kwaebibirem district, shows a very poor historical background about the Christian faith's engagement with the cultural values of the people. This situation arose because of what Idowu, as cited in Asare (2008) describes as the 'prefabricated theology and church traditions' which gave birth to these churches. Idowu still believes that the missionary churches 'failed to lay the proper foundation for gospel message in the heats of the people'. The result has been that, 'no bridge was built between the old and the new', i.e. the traditional religion and the Christian faith. Instead of building bridges between the two cultures, the missionary churches, in Idowu's $(1968,433,434)$, estimation, have been 'speaking to Africans in strange tongues because there was no real communication'. What this mean is that within the Kwaebibirem district, the church has on her hands communities of believers who, by and large live ambivalent lives'. Christianity, to such believers is therefore only a fashionable religion 'which has the habit of beginning and ending in the walls of a church building' called chapel.

The real or vital lives of these Akan Christians of the Kwaebibirem district have not been touched and so Idowu (1968,433), believes the 'vital areas of personal needs' of these Akan Christians are never fully satisfied. Thus, it is possible to have these same Christians of the Kwaebibirem district metropolis, as Idowu puts it, 'to sing lustily in church "other refuge have I none" and still carrying an amulet somewhere on his person'. Such a person can then go 'out of the church straight to his diviner, without feeling that he is betraying any principle'.

According to Afriyie (2010, p. 4), 'the fact that Jesus occupied the throne of the convert's world having removed all idols that used to reign them does not mean that the convert is made a being without culture'. As such it should be noted that the fact that the Akan of the Kwaebibirem district metropolis have been converted to Christianity does not mean that his culture is taken away from him. Afriyie further stated that 'as long as we continue to conceive conversion as being only an individual experience, the issue of conversion and culture will continue to exist as the individual having turned to Christ still lives within a culture that is itself not turned to Christ'.

In other words, the fact that some individual Akan people of Kwaebibirem district have become Christians, does not mean that the whole of the Kwaebibirem district metropolis has become 'Christianized'. Conversion is seen as an individual matter devoid of community involvement. In addition to that the 'new convert' has been shaped and will continue to be shaped by his cultural values as long as he continues to live within that cultural environment. in the view of Safo-Kantanka (1993,67), as 'an Ashanti, and a member of the Oyoko lineage, I do not cease to become one when I become a Christian' (p.61). As a member of that lineage, the chances are that such a person could ascend a stool if there is one in that lineage. If as a Christian, such a person accepts to become 'a chief as part of a total effort towards evangelization', the church should then recognize that it has a major role to play in helping such a person to live as a Christian chief. 
As a result of this misunderstanding or ignorance about Akan cultural elements, comments about influencing Christian worship with Akan Cultural elements by scholars such as Sarpong, Dickson, Dovlo, Sarfo-Kantanka and others sounded 'syncretic' to many evangelical Christians.

This situation is due to the fact that many of these Akan Christians of the Kwaebibirem district metropolis who raise such issues are ignorant about the relationship between cultural elements and the Christian faith. To help such Akan Christians of the Kwaebibirem district then, is the isolation of cultural elements which, according to Sarpong $(2002,36)$, are "worthwhile" so that they could be 'animated' to enhance Christian worship among Akan people of the Kwaebibirem district.

\subsection{General differences between Christianity and African traditional religion}

According to Boafo (1908), the main difference between Christianity and African traditional religions exist in the domain of their respective claims ad in their organization. Above all, they differ on how a human being enters blessed eternity in the presence of a holy and just God. In African traditional religions there is a faint line between humanity and the world of the spirits. Communication with the spirit world is the norm rather than the exception. God speaks the language of the people, the gods speak the language of the people, and the ancestors also speak the language of the people. Christianity, Boafo (1908) maintains that God does not permit it adherents to communicate with any spirit apart from Him. God also forbids any attempt to contact the spirits of the dead. (deut 18:10-11) there shall not be found among you any one that makes his son or his daughter to pass through the fir, or that used divination, or an observer of times, or an enchanter, or a charmer, or a consulter with familiar spirits, or a necromancer). Certainly the scriptures to that at time angels talked to human beings. Angels approached Abraham; an Angel talked to Joshua; an Angel appeared to Mary; and an Angel appeared to the woman who visited Jesus' tomb. Yet it is clear that the humans involved did not initiate these encounters.

On the other hand, African Traditional religion may be called nature religions, because they are generally directed towards the maintenance of vitality in the life and society of the natural man, while Christianity's emphasis is on a special spiritual kingdom centered on a unique individual, Jesus Christ, who is both God and Man. He is believed by Christians to give sinners forgiveness and to present God's new creation. In this regard, Christianity sees the Divine Being in terms of a unique person revealed and involved in history, Jesus Christ of Nazareth. (Through Him God the creator, who is also a Redeemer of creation, is fulfilling His will and purposes). For the African traditional religionist, the creator supreme God is not far removed from human involvement, believing that divinities and ancestors serve as intermediaries between man and God. Through them God is accessible to humankind. Christianity's strong ethical consciousness is based on God's action on behalf of fallen humanity (Colossians 3:1-3). For the adherent of traditional religions, God is believed to set the standard of righteousness through intermediaries.

That is why, for example, people say that somebody does not fear God when he commits a heinous crime. Therefore, Righteousness is to honor and sacrifice the Supreme Being to gods and ancestors, and to observe ethnic norms of behavior and taboos. But when the Bible gives it readers explicit ethics and morals, it is God who sets the standard for righteousness. At the same time, he also gives righteousness and empowers righteous living of anyone who is "in Christ". A person is righteous in God's sight when he or she trust Christ as the truly Righteous Savior. In Christ is the central revelation of God's grace and forgiveness (Isaiah 59:14).

Unlike traditional religions, Christianity is not rooted in one land or race of people but is universal. According to Christianity, God speaks to individuals and groups of people across all cultures. God as creator and Redeemer gives each and every individual a special sense f worth and dignity. Human self-esteem is not dependent upon God esteeming individual by saving them in Jesus Christ. In African traditional religions. The knowledge of God is just like a natural inheritance: passed from generation to generation. Giving the group rather than the individual the sense of worth and dignity. With reference to Akan religion, for example, .B Dnquah was noted to have said that "Akan religion, in its highest expression, is the worship of the race." (Ebenezer Boafo, communicating the message about Jesus to African Traditional Religionist, 1908).

Christianity has a sacred book, creeds and dogmas. It also partly expresses itself through cultic rites and religious practices. African traditional religions are expressed mostly through cultic rites and religious practices. Oral tradition and repetitive rituals convey beliefs in traditional religions. Boafo (1908) and Hiebert (1978) classify Christianity as a high religion and traditional religions as a low religion. A high religion is systemized and wellorganized. "high" religion places emphasis on the high God and cosmic ideologies. Low religions place emphasis on how to control spiritual power. Their main concerns are pressing earthly issues. However, it should be noted 
that the distinction between high and low religions depend on the bias of the speaker's or writer's religious affiliation or tenet.

\subsection{Methodology}

This chapter describes the research procedures used in conducting this investigation. The population and the selected sample and sampling procedure are also described in this chapter. The development and design of the instrument, details of the methods of administrative of the interview guide and data analysis are also described here.

\subsection{Research design}

The research design that was used was the descriptive survey. The design sought to describe the situation as it currently exists

\subsection{The Akan people of Ghana}

the Akan constitute the largest ethnic group in Ghana. The 2000 Ghana's population census put their percentage at $49.1 \%$ of the total population of Ghana. They are mainly found in middle and the southern part of Ghana. The Akan group is composed of different linguistic groups. The tongue of each group constitutes a dialect of the Akan language but most of the dialects are mutually intelligible. Two of them, Twi and Fante are however, widely spoken in the country. The Twi dialect also has two versions which are popular in Ghana. They are Asante Twi and Akuapem Twi. Part of the Akan is also found in the republic of Cote de'Ivoire. This was the result of the balkanization of the African continent during the colonial period.

The Akan people of the Kwaebibirem district from part of the major Akan ethnic group in Ghana. This is a people with a very rich, dynamic, and vibrant, but varied cultural

Heritage. This rich Akan cultural heritage which is also seen among the people of the Kwaebibirem district is demonstrated through such elements as chieftaincy. Communal living. Aesthetics, economics, rites g passage and he veneration of their ancestors. All these culminate in a deep religious life style. As a religious community, the Akan people of Kwaebibirem had all along believe in 'Supreme Being' and have worshipped Him as seen in all aspects of their daily life. In fact, in nothing, however minute, would be Akan people of the Kwaebibirem take step without offering a prayer to seek the intervention of the 'Supreme Being'. The traditional priests, the medicine men and ordinary people, before going out in public or engaging in any activity, first of all, request for the intervention of the 'Divine Reality' in whatever they have to do that day. All the rites of passage, from birth through to death, are celebrated by the Akan as social, as well as religious functions.

\subsection{Unity of Analysis and population of the study}

The unity analysis was individuals when were well versed in indigenous Akan culture, practices and tradition in the two selected towns in the Asante and Akyem lands (that is, Asante Akyem Agogo and Asuom respectively). These people included queen mothers, elders in the palace and so on. Moreover, the clergy in these communities were also systematically interviewed to better understand how the two communities have coped in an attempt to homogenize. Opinion leaders in these communities were also interviewed to get a middle position in the issue.

\subsection{Sample and sampling technique}

A sample size of 10 were purposively used for the study. The sample is comprised the queen mothers from the study areas, two elders from each of the study area, two members of the clergy each from the two study area. Similarly, an opinion leader from each of the two communities shall were selected to get holistic ideas about the subject matter. The purposive sampling technique was employed to select respondents was possessed by these specific group of people. Even though the researcher recognized that this needed, a case studies like that.

\subsection{Data collection procedure}

Primary and secondary data were collected for the study the primary data was the information from existing literature. 


\subsection{Instrumentation}

Semi-structured interview guide used to collect data in this study. As Gall Gall and Borg (p. 228) stated, the advantage of interview is its adaptability; skilled interviewers make an effort to build trust and report with respondent thus making it possible to obtain information that the individual probably would not reveal by any other data collection method and also can follow up a respondent's answers to obtain more information and clarify vague situations. Interviewing is a way to collect data as well as to gain knowledge from in individuals. Interviews are oral questionnaire conducted in which the interviewee gave the needed information verbally in the presence of the interviewer about leadership in some places in Kwaebibirem. Interviews helped to bring out confidential information than any other data-gathering device. On the part of the interviewer, he had the opportunity to explain further to the interviewees the purpose and kind of information he wanted about the Akan leadership and how it has been influenced by Christianity. Interviews were conducted among the chiefs' representatives, clan heads and curators. The researcher used interview guide to conduct face-to-face interview among the respondent.

\subsection{Administration of the interview}

Interview schedules were taken to some palaces at the suburbs with in Kwaebibirem district were with permission from chiefs, interviews were conducted. It started from the chiefs' spokesperson down to the opinion leaders and clan heads. Questions were asked on the introduction of Christianity in the area and their perceptions on how it has impacted on traditional Akan leadership. This was done together with the members of two churches which were selected. Hence a focus group discussion was used.

\subsection{Data analysis}

As regards the interview schedule the data collection produced essentially qualitative data. This data was analyzed thematically as advised by researchers Creswell, (2005) and Grbich, (2007). In using this strategy, the researcher organized the data gathered and got immersed in the data while transcribing it. After this was done, theme generated were coded and were described. The first stage was a preparatory where the interview data for presentation began with the organization and transcription of the audio-tape recordings. The transcription involved listening to each tape repeatedly to familiarize myself with the conversation and carefully writing them down in the words of each interviewee. The interview data was then categorized into themes of responses for effective management and comparisons. The next stage involved intensive and repeated reading of the data with the aim of immersing myself in it and to determine analytical categorizes or themes (Schmidt, 2004 and Creswell, 2005) using my professional judgment (denscombe, 2003), the development of the themes was guided by the research questions and the literature review. The coding process began after determining the themes. The respondents were coded to avoid identification. Contributions, responses and comments made were not attached to names but the codes. Brief quotations from the data were used to add realism to the description (Creswell, 2005). Since the data was collected from different categories of respondent, it was analyzed from their perspectives in order to build some kind of complexity into the study (Creswell, 2005).

\subsection{Data Presentation, Analysis and Discussion}

This deals with analysis and discussion of the data collect for the project. The analysis as contained in this chapter, deal with the characteristics of the respondent participated in the data collection process and the nature of information they gave out. It also contains analysis of respondents' view on Akan leadership formation, and values the society requires its leaders to possess. This is then interpreted along with the discussions by drawing analogy and pulled opinions as they have been expressed by other respondents and authorities in the subject matter under discussion; Akan leadership formation and the role Christianity has played in its procedures and practice since their encounter some centuries ago. Participants were represented with RP.

\subsubsection{Characteristics of respondents}

In all twenty respondents were involved in the focus group discussion (FGD), 10 males and 10 females. Due to the nature of information needed, I purposively selected people of the ages of 5 and above. Two communities of the Kwaebibirem district, ASUOM AND Abaam were selected for the project. Four different discussions were organized independently for the purpose of retrieving information from respondents in these communities. The first group consisted of five female members of Asuom community. Out of these, two were elderly members from the chief's palace, two from the Christian community (one Presbyterian and a Methodist) and an elderly member from Amankwakrom a suburb of Asuom. The second group which consisted of five men was made of two people from the chief's palace, two from the Christian community and an elderly man from the town. The third group was 
made five women from Abaam in which the sampled method was used to select them. And the final group consisted of five men from Abaam with the same procedure used in selecting the men from Asuom was used.

\subsubsection{History of Christianity in kwaebibirem}

In order to better understand the historical trajectory of Christianity in the area and the extent of influence on the traditional leadership formation and the culture and tradition, there was the need to find from respondents a brief history co Christianity particularly in the area.

It will be very difficult to tell when Christianity was introduced in this area. As far as I am concerned little has been told and documented on the arrival of Christian missionaries in Kwaebibirem. [RP-3].

From our interactions, it became evident that, the exact date the missionaries arrived in these communities is not known. It can be drawn from the conversation that the arrival of the missionaries was early $19^{\text {th }}$ centuries. They had had contacts with the missionaries, the earliest being the Basle missionaries.

Meanwhile, differences occurred in the two towns about the new religion was accepted and spread. Whereas the Abaam groups were certain the missionaries face little challenge from the indigenes as evangelism started, they faced some stiff resistance from the local people when they arrived at Asuom. The reason for this situation according to the Asuom group was due to the indigenes deep rooted belief in their traditional fetish that worshiped in the main river of the town Appam (they referred to him as Apaamkomfo).

Thus, it took some time for the people of Asuom to accept the ne religion whilst other surrounding communities had accepted it. Up until now according to respondents, the people of Asuom still have some tendencies to go beyond their Christian teachings and practices to seek answers from the priest of Apaam and other traditional deities.

This mindset as one woman said, will take a lot more generations to entirely erase from this town and a man even posited that it is now part of our people (Auom people) natural psyche and may not be able to get rid of it completely.

\subsubsection{The spread of Christianity in the area}

Deliberate actions were taken by the missionaries to win souls for Christ. These made the new religion much more appealing to the indigenes that with time became attracted to and joined the missionaries in propagating the gospel. Among the numerous evangelistic measures according to respondents are discussed below.

from the little we are told, Christian missionaries who were here were very zealous for the work of Christ. Within short time Christianity had gained grounds in Kwaebibirem and its surrounding villages and towns. [RP-4]

The missionaries tried as much as possible to convert the inhabitants to Christianity and by so doing the people were given gifts, food and other incentives to convert them. So were some of the sub-chief converted [P-2].

Through our interactions it became clear that, the local people began to embrace the new religion through a variety of incentives put forward by the missionaries. According these eminent personalities, the Basel mission upon their 'acceptance' into these communities' established Salem communities where the new converts and the missionaries lived. These communities were exempted from some traditional practices and obligations which made them concentrated on their crusade activities.

The Salem communities were not allowed to observe the fortnight ban on drumming and noise making prior to the celebration of the local festivals, Ohum which is held twice every year and the Odwira festival. As traditional authorities exempted the sales from ban on noise making including pounding 'fufu' (a local food), a lot of indigenes chose to join them and by so doing they became converts.

Another measure which motivated the local people to convert to Christianity was introduction of formal education. According to the Asuom proud, the established of Basel (which later became Presbyterian) elementary and middle schools for their members and the larger community. One of the middle school is now called local Authority (L/A) junior High School (JHS) and the other Presbyterian JHS. 


\subsubsection{Formation of Akan Leadership Systems}

The forms of traditional leadership system that existed before the missionaries came to the area were raised for discussion. The leadership system prior to the arrival of the missionaries was a linear and unidirectional number. Beginning from the basic unit of society the family ending the most important level at the state level, the paramount king/chief. From the interactions, both Asuom and Abaam groups raised similar points on the issue. They mentioned that the kingship system with the King or Chief as the head of the paramount area was important and sacred as far as the Akan leadership system was concerned.

They went further to state that, the kingship system as it existed before the missional came to their communities was a venerated institution and revered by all. They were seen according to the respondents, as the link between the living and the dead or the ancestors. Indeed, among the Akan's, the chieftaincy institution is the most valued establishment serving spiritual (religious), military, judicial and law making functions of society. If a king is killed in warfront in some cases, it formed enough bases for the war to end since it is presumed that the said group has been defeated. According to a man. The king declared war and make peace. Therefore, if he is killed during war the morale of his living subjects completely dissipate and in most instances they runway in defeat. They might restrategize and come another time after a new king is installed or the group is taken as a vassal[R-3]

Another important leader seen in the Akan area before Christianity was the queen mother. The queen mother was an influential leader in the Akan traditional leadership formation. It was therefore not surprising that her role as a leader was strongly pushed forcedly by the female groups in both communities during the discussion. Even though the male group talked about the important role of the queen mother in both past and current Akan setup, it was not as passionate as the women groups. A woman pushed strong an argument to buttress the significance of queen mothers in traditional Akan societies; 'queen mothers were and are still our (women) organizer, educator, and the symbol of women status in his male dominated society. The role given her as the person to select the rightful successor to a vacant stool and the fact that she is seen as the mother of the state emphasis her stature and command in our society [RP-6].

The above point is in line with what has been said and written by commanding author in African traditional customs and practices. For instance, Nana Addo Danquah the III (CHIEF of Akuapem traditional area) has indicated that the 'Ohemaa' (Queen mother) 'was' an individual who ensures the selection of right candidate to traditional office. He goes on to state that, in the Akan traditional set-up, it is necessary as far as possible, that the blood relation of the original heads of the family, whose memory is preserved with the original black stool, be chosen as a chief of all times. To make sure that this arrangement is strictly adhered to, the Queen who is deemed or accepted as the 'mother' is made to identify one of her true 'sons' to be selected as chief. He further argues that the 'Ohemaa' performs the identification of the candidate to occupy traditional office due to her knowledge about the royals (Opuni-Frimpong, 2012).

Other forms of leadership system that existed but all were subject to the chief/king's dictates were the Odikro, Abusuapanyin (family heads). another important leader in the society then were the spiritualist, the fetish priest who even though wielded some power he was still under the command of the chief/king and was answerable to him and his direction in Akan societies.

\subsubsection{Leadership Formation: chieftaincy}

Akan's attach great significant to their leaders. The nature of the Akan indigenous leadership formation can be examined during the pre-installation, confinement, and post-installation phases (Opuni-Frimpong, 2012). Thus, discussion with respondents were on these three stages in leadership creation of Akan societies.

\subsubsection{Pre-installation and installation periods}

Leadership formation among the Akan royals begins before the installation process. This process includes royal consciousness, mentoring, service in the Palace, and confinement as it has been espoused by Opuni-Frimpong (2012). Any member of the royal family at any time can have access to the stool or throne. Such a person according to Busia, should possess certain characteristics aside being a royal. Anyone who is nominated should be intelligent, humble, generous, mainly and without any physical disability. According to respondents, once a person is selected to inherit the throne, a grooming exercise begins. A woman from the Asuom traditional council explained further. 
No matter his level of education, being trained in the traditional Akan values and history is preeminent and our fore fathers never joked with it. Therefore, it's our duty to keep tradition on and abide by it fully at all time. This practice has existed for all this year and we continue with it [RP-1]

The leadership formation processes therefore start before the emergence of the opportunity for selection. The selected royals were kept in Apatam for the traditional education. At Apatam, there are taught the key values of Akan customs and acceptable norms like speaking, relationship with other chiefs, self-control and history of the state. Some days are set for education, the Queen and other elderly knowledgeable women play very keen role during the Apatam period as they do a lot of education (Opuni-Frimpong, 2012). Respondent attested to an also added that "during this period nominee are made to go through training of our culture where some sub-chiefs and other people when are presents". [RP-3]

Parent are the main educational agency for the pre-installation formation. However, other member of the family and the community elders play active role in the process. The process also involves royal consciousness or mentoring, service in the Palace all in an attempt to make the chosen personality dedicated and loyal to the state. As far as mentoring is concerned, every Akan chief before enthroned is made to understudy a knowledgeable personality even at a deferent state where necessary for him to acquire the Akan tradition and knowledge. Respondent generally supported this practices and assert that, "this practice has made traditional leaders more knowledgeable on our traditional customs and practice. In particular, they become sensitive to our culture and adhere to age old commitment and imperatives." [RP-2]

The pre-installation formation processes in Akan traditional leadership providing service in the palace. Outsider may presume that royal do not involve themselves in menial service due to the high sense of recognition associated with Akan royal. Respondent strongly supported this assertion and said that "by getting involve in palace service royal get the opportunity to learn desirable practices and values that are associated with the palace life." [RP-1]

Royals who are eventually selected for Akan traditional leadership are confined for a systematic leadership formation. The confinement take place in different places, depending on the particular community. The confinement period creates the opportunity for the people, who are knowledgeable in traditions, to gather around the new leader for effective teaching and learning. Respondent observed that the confinement initiates the new leader into the chieftaincy institution.

\subsubsection{Installation}

On the day installation, the chief is made to swear an oath to the entire state ina gathering of sub-chiefs, queen mothers, family heads and the rest of the society after the confinement phase. The oath swearing according to the respondent is seem as an unbroken pact between the chief and his subjects. Should he go contrary to the oath, is seen a betrayal of trust ad may for enough basis for is impeachment. The respondent generally agrees that "the oath is the legal bond between the subject and chief and by swearing, he promises to behave himself, protects the state, and ensure that all customary practices in the society is well adhered to by all." [RP-4]

This practices are also seen as a social contract between traditional leaders and their subject. It has been argued that oath is not only a social contract but also provides political direction for the rulers. Nana Addo Dankwah III has noted in (Opuni-frimpong, 2012) that, our ancestors, therefore, instituted oath-swearing systems, which in effect, is a sort of social contract binding both family offering leadership and the families forming the community to observe strictly in the agreement they had accepted. The leader has jurisdiction over all the members of the community and gave political direction, led tribal armies to wars, settle disputes administered land and did many act for the good governance of the community. The people and the new leader set up together the parameters of power and authority, the breach of which incurs removal from office. This therefore provide the grounds for traditional leadership formation. It also provides the opportunity to offer deep information not only to the new leader but also the larger community. The core values of the oath-swearing education for the leader, is to be Godfearing and willing to serve the people. During the installation period Akan traditional leaders are also made to select and announce their stool names and thus the name they will be called henceforth.

\subsubsection{Post- installation - Destoolment of non-performing leaders}

As the chief is sworn into office any action of his actions words so said that denigrate the kingdom and may be judged to be breaking his oath my result in his removal. Removal from office is linked however, to the neglect of the leader's oath and vows to the people and ancestors. Before the destoolment process is initiated there must be enough grounds to demonstrate violation. A chief who is enstooled is regarded by many as a failure. Most 
respondent went along with such interpretation and states that, if a leader goes contrary to his vows and promises, then there is the need to replace him with another who is credible and who will rally all members of the society around him. Things that may warrant removal of traditional leader are numerous and include visiting other people's wives, collective monies from people, allying state assets without due consultation and approval, indecent talk and any other behavior considered as disgrace to the state may warrant removal. [RP-8]

A traditional leader is not instantly remove from office if a case of misconduct is leveled against him. He is advised to stop such a behavior and revert any misconduct. However, after giving him enough time to learn, if he is not prepared to learn, elders will have no option than to remove him from his throne. The failure of traditional leadership formation on the part of the elders is when they keep accepting responsibility for mistakes of the leader in the hope of correcting him.

When the elders decide not accept the responsibility of the leader any longer, they are indicating that they have exhausted the formation the formation processes and therefore, the failure of the formation of the leader is due to his inability and unwillingness to learn. The acceptance of the mistakes by the elders demonstrates the fact of continuous formation in the chieftaincy institution. This shows that the Akan concept of education and formation is continues and lifelong.

\subsubsection{Are Akan leadership formations waning?}

It became imperative that participant ere asked of their views whether they perceived Akan leadership formation were waning. Different views were shared as far this question was concerned. The following themes were gathered from the responses given by the participants.

\subsubsection{Softening of certain rules and regulations}

It was shared by the participant that, with the influx of churches and propagation of Christians principles certain punishment meted on culprits have been softened. This was shared:

Our leaders of today are not like that of the olden days. This is because earlier, instant justices were taken on cases and offenses which were criminal like killing someone. But now are handed over to the police for the laws of the land to deal with you. [RP-9]

Another view was shared by RP-1 that "there were instances people were expelled from the village or the community because of an offense. With the widespread of Christianity chiefs are drifting away from these practices." [RP-10]

\subsubsection{Authority of the chief or leader}

The authority of the chief remains resolute. Not much has really change with how the chief exercises control or authority over his people. My concern here will be that they are liberal on how stringent they are even though they do this in a way that still maintains their respect [RP-2]

Another view was shared on the authority of the chief which widely applauded when this raised.

In some decades back a dead chief is believed to still continue his ruling even in his spiritual world. Because of his culture, people were slaughtered and made to carry the body of the chief in the grave. Presently, the chief openly confess they detest that culture and that no human head should be caught to carry his body. With Christianity, most of the people have come to understand the cruelty of this culture. [RP-8]

\subsubsection{Influence of Christianity on Akan leadership formation}

Many contemporary Akan traditional leaders have received missionary pattern of education and might have as well been involved in Christian leadership. Some of them might have reached the highest form of education, the university. However, when an individual is nominated for Akan traditional office, no matter the level of their education, they would be nurtured in traditional leadership knowledge and values. The royals are trained to acquire the desirable public behavior and comportment. The quality of traditional leaders in Akan world-view cannot be compromised and the best way to guarantee it is to let the royals undergo indigenous leadership formation processes. 
With the encounter of the Akan's with the Christian missionaries, how have these leadership systems changed in this community into the future as they continue to exist side by side in a conflict of harmony in these societies? how are things going to be? It became evident through our interaction that since Christianity was introducing some century or so ago, the way chieftaincy was perceived has changes among 'a new generation' of Christian subject who now form majority of society. This has made the august institution lost some steam loose large part of their powers they wield pre-Christian Akan societies especially so when the system of government also vests authority and resources in state bodies and organs. A woman out of frustration to this subject emotionally said;

'Nowadays people treat chiefs like empty symbol of our society, when they talk no one pays heed to it and customary laws, are not given the due regard for that matter when chiefs pass any important laws community members do not take such laws serious and they disobey them as though not important person promulgated it, and I am saddened by it, [RP-13]

During the men's discussions with the Asuom group, one of them also said that,

'Our chiefs today are not regarded as they were in the olden days. In years past, they were seen as the symbol of power and authority. They talked and it became laws. Passed judgment and all heeded to their judgment and when they die the whole community s bereaved. They were able to rally the entire community around them and they lived in peace and unity. But now nobody in this society take the chiefs word serious [RP-3]

Moreover, $\mathrm{n}$ days past actions which could be a basis for a chief's removal from his throne is now considered normal and no attention is paid to it. For instance, traditional leaders were symbols of traditional religious practices where they poured libation, offer sacrifices to the gods and the ancestors. Even though, all these practices are done now in some more refined ways most chiefs are known members of a particular Christian denomination or the other and they not seen as sacrilege.

\subsubsection{Points of disagreements}

When asked what might have accounted for this situation, the current problems they gave a litany of reasons. For instance, RP-7 said

The system of government we are operating now where the state led by the president is seen by the society as the most important person waned the attachment the people have with their chiefs. Moreover, the constitution rule has therefore made chiefs and customary laws less impotent than they used to be some years ago.

However, most of the women argued that the most important reasons for the waning of trust, authority and attachment in traditional leaders are largely their making for example; a woman said this to make her point;

The numerous chieftaincy disputes generally resulting from succession problem have made the respect for traditional leaders declined in the eyes of their subjects and that this situation cannot be attributed to any other body but the royal families themselves [RP-6]

Effects of Christianity on the various elements of the social life of the African were discussed by all groups and the findings are as follows;

\subsubsection{Christian influence of Akan language}

The Akan language (Twi) is one important aspect of society that has substantially gone through evolution since the Christian missionaries arrived here. Among other things, the missionaries for the first time put local language into writing by the written of the Twi dictionary. By this singular action of the missionaries, the Akan's can now document their own history and the happening of the time and with the aid of oral history and archaeological finds have reconstructed their past. A man in contribution to the issue said.

The art of writing as the Basel Missionaries introduced our language has helped us better record not just events and things happening, we now even guess what our forefathers did, thought about and some of our proverbs and other wise sayings we came to meet, giving the future generation better understanding of their past. [RP-3]

Others highlighted the translation of the Holy Bible into the local Akan language, Twi. This according to the respondents wooed some people to Christianity since they can now understand the word without a third explaining to them. A woman passionately passed a comment that, 
We can now read and write, and by ourselves interpret and make our decisions about the Holy Bible and Christianity as a way of the life. Our fathers and mothers in the distant past could not write what occurred in their era and so were passed on by word of mouth which decayed with time. We are so fortunate and all thanks to the early Christian missionaries who came to this area this is made possible [RP-9]

Meanwhile others raised issues about the negative influence Christianity and western language hashed on the Twi language. The Akan language existed before the introduction of foreign languages like English, in the process of translating the Bible into the Akan language, concept like named (knowledge), adesua (learning) and adekyere (teaching) that were used in indigenous formation were adopted. The adoption of the concert in the translation of Akan Bible for example, should have gave given African traditional education legitimacy earlier by western missionaries' movement.

\subsubsection{Traditional rites in a Christian era}

Influence of Christianity in the private and public life of the Akan has been so enormous that rites performed at the basic level of society have seen some dramatic change. Among these are puberty (bragoro) and widowhood (kuna) rites performed as a passage of life and human sacrifice done to pacify the gods if there were calamity in the society and the death of kings and chiefs have all been done away with. Most of the women expressed similar opinion pointing to the general abolishment of these negative practices which favored women the least. Contributing on the issue one of the woman said,

These rites were detrimental to women welfare in society and the main reason for their gradual elimination from our society is largely have due to introduction of Christianity and Christian principle and practices and practices here. We no longer have these rites and sacrifices which made our society unsafe for large segment of the population at the time if it was practiced. [RP-5]

\subsubsection{Perception about Traditional Practices}

Christian ethos has permeated deep into Akan society and psyche according to respondent and has affected the thinking of common Akan person. Some traditional practices have seen significant transformation since the appearance of the missionaries some century or so ago and the old ways are now seen as out dated and in extreme cases been described as barbaric and uncivilized. Among these practices are polytheism. Polygamy, and human sacrifice. Even though respondents agreed that some of these practices like polygamy still exist in Akan societies, their incidence has reduced considerably. Other cultural habits of the Akan have also seen changes which according to respondents which are attributable to the Christian influence. These include architecture, eating behavior, dressing pattern and so on.

\subsubsection{Christianity influence on local festivals}

Traditions festivals have long been celebrated by the Akan's to build social bond and nitty among the various clans and towns to enhance solid statehoods, empires and chiefdoms prior to the coming of the missionaries. Their importance then has endured through time and generations. Major festivals celebrated in Akan societies include the AkwasidaeKese of the Asantes, Odwira among the Akuapem, Denkyira, Akwamu and Akyem peoples, and Ohum among mainly the Akyem. It was an occasion where sub-chiefs and clan heads renewed allegiance to the paramount and new pledges are made for the coming year.

As far as local festival is concerned, there was a general consensus among respondents that large part of the processes leading up to the event has remained without any substantial changes especially by Christians principles. However, respondents were quick to add that some Akan societies end the weeklong event by holding church service and durbar. Moreover, during these durbar, some Akan communities allow Christian prayers to be said, confirming the special influence Christianity has had with the Akan system in totality.

\subsection{Summary, Conclusions and Recommendations}

The Akan of Ghana possess indigenous patterns that are used in the formation of its members. The Akan indigenous formation patterns have remained and continue to serve the formation needs of the people, despite the introduction of missionary patterns of education. It has been established that the Akan indigenous formation patterns lack book culture as may be found in Christian education. It has largely remained among the pet-installation, installation and post-installation periods. The pre-installation Akan leadership formation is built around royal consciousness, mentoring and service in the place. Royals are nurtured from infancy by parent, family members and knowledgeable members in the community to be aware of their status as royals and therefore, the need to adopt 
lifestyle that depict their identity. The installation period suggests the existence of systematic traditional education for selected leaders. Leaders are confined in various places as part of the formation process. It is the moment that the kingmakers ensure that all that ought to be taught and learnt have properly done before the new the new leaders are allowed to swear the traditional oath which serves as a social contract between the people and the traditional leaders. destoolment and achievement of ancestral status serve as major indicators in assessing the failure or success of Akan traditional leadership formation. However, leaders, who have been given recognition as ancestors, are considered as successful and worthy of education. Continuous leadership formation patterns, the black stool, Okyeame and the Ohemaa are the structures that the Akan use in their effort to avoid destoolment and ensure successful leadership performance.

\subsection{Summary of findings}

The following were found:

1. it was affirmed Christianity has had influence on the traditional Akan leadership

2. Fetishism also contributed to leadership development in the area.

3. At Abaam they established elementary and a Middle school which taught the new converts the Gospel and also offered them formal education.

4. Other deliberate policies which were introduced by the missions in order to win souls for Christ as they termed it are employment offer to new converts, and security provided to the vulnerable and weak in society. That is, the missionaries offered job employment or new converts as catechists, teachers, and laborers in the newly established schools and churches.

5. All these respondents recounted by mentioning families who were direct beneficiaries in both towns (Asuom and Abaam). Moreover, outcasts from society were shelter and housed at these ne suburb, the salems.

\subsection{Conclusions}

The following conclusions are drawn from the study

1. It is obvious from the research findings that Christian theologian of the Kwaebibirem are fully interrogating all the rich cultural values of the Akan in order to develop Christianity in them.

2. There is also enthusiasm in incorporating Christian values in Akan leadership in but kwaebibirem district. 3. The culture of the people which could be term as wicked have gradually waned due to Christianity in the area.

\subsection{Recommendations}

1. In order to preserve the core aspect of the traditional leadership system, there if the need for deliberate integration into the school curriculum at the basic school level in the Akan areas just as native language used as the language of medium of instruction at the lower primary. This is crucial to preserve and transfer the rich culture which involves education, grooming and showcasing one of the last remaining traditional institutions in the face of Christian dominance in the Akan areas. This will help blend the sweeping Christian ethos in modern Akan societies and the custom of the people in which they derive identity and heritage. Thus, by making it part of the educational system, its understanding and importance become pervasive and resilient.

2. Traditional leaders who have had Christian education should find a way of modernizing and demystifying the institution through sensitization forums. One way of demystifying traditional leadership is to take advantage of opportunities offered by festival celebrations. During these occasion, people from all works of life are brought to these communities and more importantly indigenous near and far are also brought home. As festivals attract attention in Akan societies, it should not just be merry making ceremonies but a period toil so sensitize people on the need for such traditional leaders once in this modern era.

3. There is the need that Akan traditional ethos is encouraged during festivals to promote the rich cultural heritage of the people.

4. The Omanhene, organization and other bodies must organize trade fairs in Kwaebibirem traditional area to attract more people to know more about their culture activities and events such as expos, bazaars, exhibitions, should be organized to motivate people to come home regularly.

5. The adoption of Christian practices like the use of brass band with Christian songs can be minimized and rather traditional songs and philosophies should be encouraged to promote the African ideals. 
6. Akan traditional songs that promote Akan virtues must be played for during ones to be inculcated and feel pound of their culture especially in these times of dominant Christian values.

\section{REFERENCES}

Addo- Fening.F. (1985. Studies of church and state: Historical review of interaction between the Presbyterian church and traditional society. Institute of African studies review. Vol.1.2, July.

Adubofour.S.B. (1987), Akan cosmology and Akan Christianity in contemporary Ghana. unpublished MTh. Thesis. University of Aberdeen.

Afriyie, E. (2010). The theology of the Okuapemhene's Odwira and illustration of the engagement of the gospel and culture among the Akan of Akropong- Akuapem. Unpublished PhD. Thesis Akrofi Christaller institute of technology and culture, Akropong-Akuapem.

Agordoh.A.A. (1991). Traditional musical elements in Christian worship in Ghana. The case of the Evangelical Presbyterian church, Ghana since 1847. Unpublished MPhil thesis institute of African studies, university of Ghana, Lagon

Agyeman.F. (1988). Amu the African: A study in vision and courage. Accra: Christian council of Ghana, Asempa publishers

Akrong. A. (2000). Traditional religion and Christianity: friends of foes? Trinity journal of church and theology Vol januaryNos.1\&2.

Asare, H.I. (2008). Refining African Beliefs. New York

Baeta, C.G. (1975) Christianity and culture. London. SCM

Bediako.K. (1995). Christianity in Africa. Edingburgh university press.

Bediako,K. (2000). Jesus in Africa Regnum Books international.

Bediako,K. (2001). Scriptures as the Hermeneutic of culture and tradition. Journal of African christianthought, vol.4.no.1 June 2001. Npublished ACI Lecture handout.

Busia.K.A. (1968). The position of the chief in the modern political system of Ashanti. London: Frank Cass

Danquah.J.B. (1968). The Akan doctrine of God: a fragment of Gold Coast Ethic and religion, (second edition). London: Cass, Megasa.L.1997. African Rligion:the Moral Traditions of Abundant life, Nairobi: Paulines publications Africa.

Idowu.B. (1995). God in Yuroba Belief (Plainview: publications, rev. and enlarged

Douglas. E.T. (2005). African traditional religion in the modern world. McFarland company inc, publishers.

Hanson.N. (2009). Culture. London: peter Owen Limited

Khan, S., \& Loostvoet B. (001). Tribal Authoity and service delivery in the Durban uni-City'. Paper presented at Governance et Governance urbain en Afrique Australe, Lusaka.

Manuh.T. (1988). Asantehemaa's court and its jurisdiction over women: A Study in legal pluralism. Research review, 4(2) pp50-66.

Mbiti, J.S. (1968). AFRICAN Religions and Philosophy, Oxford: Heineman Educational publishers.

Mensah,K. (2004). A brief history of art. Accra: Woeli publishing services.

Monmah,N.(2009). Frames and References: art history and the world. New York McGraw companies. 
Ntumy, M.K. (2005). Coming with fire. Accra: advocate publishing.

Nukunya, G.K. (1992). Tradition and change. Accra: Ghana Universities press.

Odotei, I.K. \& G, Hagan(Eds). (2002). The king returns. Legon: institute of African studies.

Opoku, A.K. (1978). Wes African traditional religion. Ghana: Fep International Private Limited.

Opoku. N.M. (2009). Religionand art.London: oxford university press

Palmary,I. (2004). Traditional leasers in the eThekwini Metropolitan Region: their role in crime prevention and safety promotion'. Centre for the study of violence and reconciliation.

Parker, L. (2005). Traditional leadership (revised ed.) Newayaork: free press

http:/www.wikipedia.org/wiki/religion_in_hghana.htm(5/10/08)

http:/www.afrikaworld.net/atrcom.html(10/10/08)

http:/www.wikipedia/reliligious_conflicts.htm(26/09/08).

http://www.wikipedia.org/(christianity/religion and law research consortium.htm (3/10/08)

http:/www.wikipedia/religious_conflicts.htm (26/09/08).

http:/en.wikipedia.org/wiki/social_responsibility.htm(3/10/08)

http:/www.mensaotabil.com/centralaid/edu-grants.php.htm(12/10/08

www.nationmaster.com/encyclopedia/african_traditional_religion(15/10/08)

$\underline{\text { www.air/community.tm(3/10/08) }}$ 